\title{
HOW LIMNOLOGICAL VARIABLES INFLUENCE THE OCCURRENCE AND ABUNDANCE OF A VISUAL PREDATOR IN AN INVADED RIVER-FLOODPLAIN SYSTEM
}

\author{
Amanda Cantarute Rodrigues ${ }^{*}$, Bianca Morelatto Dal Vesco ${ }^{2}$, Carolina Mendes Muniz', \\ Carolina Pedrozo do Nascimento ${ }^{1}$, Gustavo Faccin Andreotti ${ }^{1}$, Jonas Campaner Alves ${ }^{1}$, \\ Marcelo Henrique Fressatti Cardoso ${ }^{2}$, Marcelo Henrique Schmitz ${ }^{1}$, Maria Julia Mileo \\ Ganassin ${ }^{1}$, Mariele Pasuch de Camargo ${ }^{1}$, Matheus Gimenez Buzo ${ }^{1}$, Matheus Tenorio \\ Baumgartner ${ }^{1}$, Natália Carneiro Lacerda dos Santos ${ }^{3}$, Angelo Antonio Agostinho ${ }^{1}$ \& Luiz \\ Carlos Gomes $^{1}$
}

\begin{abstract}
${ }^{1}$ Universidade Estadual de Maringá, Departamento de Biologia, Programa de Pós-graduação em Ecologia de Ambientes Aquáticos Continentais, Núcleo de Pesquisas em Limnologia, Ictiologia e Aquicultura, Av. Colombo, 5790, CEP: 87020900, Maringá, PR, Brazil.

${ }^{2}$ Universidade Estadual de Maringá, Departamento de Biologia, Núcleo de Pesquisas em Limnologia, Ictiologia e Aquicultura, Av. Colombo, 5790, CEP: 87020-900, Maringá, PR, Brazil.

${ }^{3}$ Universidade Estadual de Maringá, Departamento de Biologia, Av. Colombo, 5790, CEP: 87020-900, Maringá, PR, Brazil.

E-mails: amandacantarute@gmail.com (*corresponding author); bmdalvesco14@gmail.com; carolina_mendes_ muniz@hotmail.com; carolinah.pedrozo@gmail.com; gustavofaccinandreotti@gmail.com; jonascampaner@ gmail.com; fressattimcardoso@gmail.com; marceloschmitzengpesca@gmail.com; mjganassin@hotmail.com; marielepasuch@gmail.com; matheusgbuzo@gmail.com; matheus_tbs@hotmail.com; natalia.ictio@gmail.com; agostinhoaa@gmail.com; lcgomes@nupelia.uem.br.
\end{abstract}

\begin{abstract}
Environmental characteristics of an invaded environment can predict the invasion success of a species, depending on its habits and life strategies. Cichla kelberi is a visual and voracious predator introduced in the upper Paraná River floodplain, an area that suffers with several upstream dams that caused many environmental changes over the years (e.g. increased water transparency). As this species is a pre-adapted species to environments that presents high water transparency, our main goal was to test the hypothesis that variables related to the underwater visibility would be important drivers of the successful invasion of $C$. kelberi in the upper Paraná River floodplain. We predict that turbidity (proxy of water transparency) is one of the major limnological determinants of occurrence and abundance of $C$. kelberi. Individuals of the invasive species and seven limnological variables were sampled quarterly between February 2000 and November 2018. This long-term data is part of the sixth site of the Brazilian Long Term Ecological Program (PELD). We fitted two regression models to all occurrence and abundance data (response variables) against the limnological variables (explanatory variables). For occurrence data, we fitted a Generalized Linear Mixed Model and for abundance data, we fitted a Linear Mixed Effects Model. The occurrence data of C. kelberi showed that turbidity and dissolved oxygen were the variables that most influenced the presence of this species, negatively and positively, respectively. The abundance data showed that dissolved oxygen and concentration of chlorophyll-a were the ones that most influenced the abundance of this species, negatively and positively, respectively. Our findings showed that besides turbidity, other limnological variables were also determinants for the occurrence and abundance of $C$. kelberi. Therefore, our results provided important
\end{abstract}


information about the main environmental drivers of the establishment process of $C$. kelberi in the upper Paraná River floodplain.

Keywords. Brazilian Long Term Ecological Program; Paraná River floodplain; Peacock-bass; successful invasion; underwater visibility.

\section{INTRODUCTION}

Biological invasions are complex phenomena and their impacts have been intensified in the last years due to human activities, reflecting in huge challenges to the conservation of biodiversity worldwide (Essl et al. 2011, Vitule et al. 2012, Simberloff et al. 2013, Pelicice et al. 2014, Leuven et al. 2017, Clusa et al. 2018). Invasive species may promote modifications in the occurrence patterns of native species and lead to biotic homogenization (Rahel 2000, Villéger et al. 2011). These modifications may result in deterministic shifts in the invaded communities and may even lead to the decline and extinction of native species (Mouillot et al. 2013). However, the invasion process and establishment success depends on a number of factors, such as biological interactions with native species (e.g., competition, predatorprey interactions; Strayer 2010) and environmental characteristics of the invaded environment (e.g., environments that are modified by humans may be more susceptible to invasions; Huston 1979, 2004). Thus, researchers have formulated hypotheses aiming to explain which factors explain the success of invasive species (Catford et al. 2009).

Many hypotheses are based on the influence of abiotic variables on the invasion process (e.g., environmental heterogeneity, habitat filtering, disturbance, dynamic equilibrium, among others; see Catford et al. 2009 for more details). According to the Environmental Heterogeneity hypothesis, highly heterogeneous environments present higher opportunities of niches, which enable the invasion success when some of these niche opportunities are not occupied by native species (Melbourne $e t a l$. 2007). Moreover, there is also the Disturbance and Dynamic Equilibrium hypothesis, which predicts that impacted (e.g., by anthropogenic actions) and naturally disturbed environments are more likely to be invaded (Huston 1979, 2004, Melbourne et al. 2007). For example, the environmental changes promoted by reservoirs filling are one of the main causes of biodiversity loss in freshwater environments, once these changes may favor the dispersion and establishment of invasive species and may trigger the decline of native ones (Agostinho et al. 2007a, Espínola \& Júlio Júnior 2007, Júlio Júnior et al. 2009, Gois et al. 2015).

The construction of several dams is known to affect the upper Paraná River floodplain, although this plain still preserves most of its natural spatial and temporal heterogeneity (Oliveira et al. 2018). Spatially, the floodplain is composed by lotic (e.g., rivers and secondary channels), and lentic environments (e.g., backwaters, connected and isolated floodplain lakes); these lakes may be temporary or permanent features of the landscape (Agostinho et al.2004a). Temporally, this floodplain is subject to seasonal alterations caused by the flood pulse (i.e., dry and rainy seasons), with different stages of organic matter input, connectivity and heterogeneity levels throughout the hydrological cycle (Junk et al. 1989, Thomaz et al. 2007). However, the several dams constructed upstream the floodplain alter some limnologic features such as water transparency, which decreases along the Paraná River reservoir chain (Agostinho et al. 1994, Stevaux et al. 2009, Oliveira et al. 2018, dos Santos et al. 2018). Thus, because of the heterogeneous environment resulting from frequent disturbances, in addition to the anthropogenic impacts, this floodplain has become very susceptible to the establishment of non-native species (Júlio Júnior et al. 2009, Tonella et al. 2018). Some of the invasive species that succeeded in this environment are the golden mussel Limnoperna fortunei (Dunker 1857) (Takeda et al. 2003), the aquatic macrophythe Hydrilla verticillatta (L. f.) Royle from Asia (Cook \& Lüönd 1982, Langeland 1996) and the fish Clarias gariepinus (Burchell 1822), an African catfish probably introduced by fish farming and escapes from recreational angling ponds located along upstream rivers (Ota et al. 2018), among others.

A major example of an invasive fish in this floodplain is the peacock-bass Cichla kelberi Kullander, Ferreira 2006 (Cichliformes, Cichlidae), a visual and voracious predator that is native 
from the Amazon River basin. This species has been extensively introduced into many South American basins for sport fishing, remaining established until nowadays in the floodplain. Its first record in this floodplain dates back from the early 90's and its main vector of introduction are escapes from recreational angling ponds (Ota et al. 2018). The invasion of C. kelberi harms the native fishes through predation and competition, once it may cause reductions in the abundance of small foraging fishes that may serve as food for native piscivorous (Agostinho et al. 2007a, Pelicice \& Agostinho 2009, Pelicice et al. 2015, QueirozSousa et al. 2019). In addition, C. kelberi has preadaptations to thrive in the lacustrine conditions of reservoirs, environments that present high water transparency (Agostinho et al. 2004b, Agostinho et al. 2007a) and it seems to favor the occurrence of this species in this kind of environment (Espínola et al. 2010).

From the information presented above, we assume that i) C. kelberi is successfully established in the upper Paraná River floodplain; ii) environmental variables are determinants of the invasion and establishment processes, and iii) $C$. kelberi is a visual predator favored by high values of water transparency in reservoirs. Our objective is to look for patterns and tendencies in the relationship between limnological variables and the occurrence and abundance of C. kelberi since its first records in the upper Paraná River floodplain. Therefore, our hypothesis is that variables related to underwater visibility should be important drivers of the successful invasion of C. kelberi in the upper Paraná River floodplain. We predict that turbidity (proxy of water transparency), whether related to organic or inorganic components, is one of the major limnological determinants of occurrence and abundance of $C$. kelberi, affecting negatively its probability to occur and its abundance.

\section{MATERIAL AND METHODS}

\section{Study area}

The study was carried at the upper Paraná River floodplain (Figure 1). The sampled area is included in the last free-flowing stretch of the Paraná River located inside Brazil. The floodplain is located between the Sergio Motta Dam (locally known as Porto Primavera Dam) and the Itaipu Reservoir
(22 $40^{\circ} \mathrm{S}$ to $22^{\circ} 52^{\prime} \mathrm{S}$ and $53^{\circ} 12^{\prime} \mathrm{W}$ to $53^{\circ} 38^{\prime} \mathrm{W}$ ), corresponding to a $230 \mathrm{~km}$ stretch and reaching 20 $\mathrm{km}$ in wide during floods. This plain is an intricate anastomosis with secondary channels, floodplain lakes and tributary rivers, carrying a high diversity of organisms, especially fish (Agostinho et al. 2007b). The sampled area presents different environments in the floodplain, such as the three main river channels (Paraná, Ivinhema and Baía), floodplain lakes that are permanently connected to the river channel and floodplain lakes that only connect to the river during high-water periods. These environments differ mainly in the water velocity (higher velocity in the lotic environments and lower velocity in the floodplain lakes) and in conspicuous limnological differences (Ortega et al. 2015). Besides, the region is mainly affected by several dams located above the floodplain and many limnological changes have been noticed over time, such as oligotrophication in the Paraná River (Granzotti et al. 2018, Oliveira et al. 2018). The other two rivers, Ivinhema and Baía, are considered as less impacted, as they are not dammed and only receive waters from the Paraná River during periods of floods.

Besides these limnological heterogeneities, the biota has also suffered with modifications along time, which has a high number of invasive fish species (Ota et al. 2018). These limnological and biotic changes, in turn, are only noticed because the study area corresponds to the sixth site of the Brazilian Long Term Ecological Program (PELD). This program contributes to research by undergraduate and graduate students, as well as professors. In addition, these researches contribute to reinforce the need to preserve the Paraná River Islands and Lowlands Environmental Protection Area ("Área de Proteção Ambiental das Ilhas e Várzeas do Rio Paraná") and the Ivinhema River State Park ("Parque Estadual do Ivinhema").

\section{Fish samples}

Fish were sampled quarterly between February 2000 and November 2018 at 21 sites: seven lotic environments (rivers and secondary channels), nine connected floodplain lakes (connected to a river in the region) and five isolated floodplain lakes (not connected to a river). All samplings were conducted using gillnets of different mesh sizes $(24,30,40,50,60,70,80,100,120,140$ and 160 


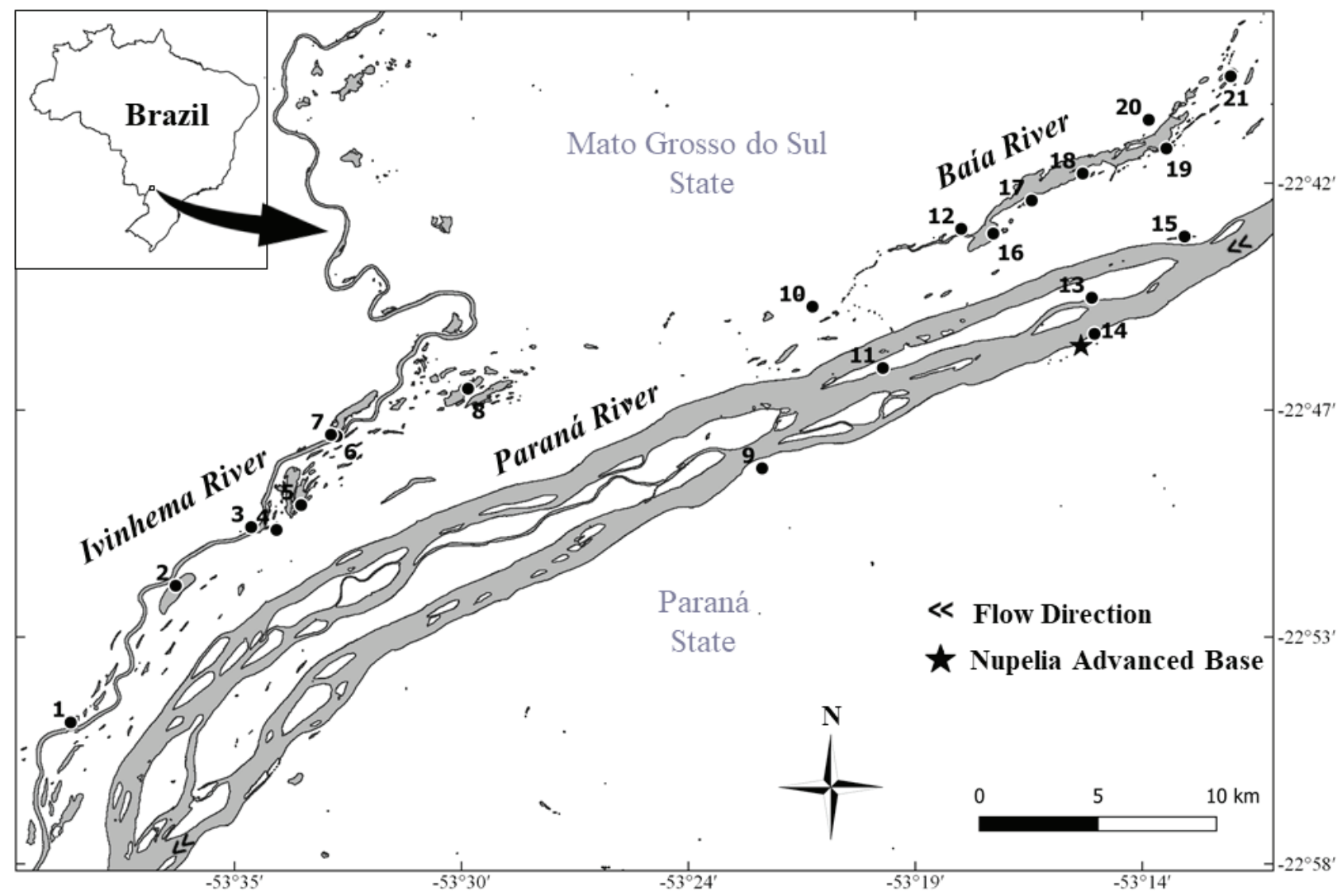

Figure 1. Map of the study area inside the upper Paraná River Floodplain. Numbers indicate the sampling stations. EPSG: 4326.

mm between opposite knots) set at each sampling site for $24 \mathrm{~h}$. After samples, all individuals were identified to the species level according to Graça \& Pavanelli (2007) and counted.

\section{Limnological variables}

Along with fish surveys, we measured seven limnological variables: turbidity (NTU), obtained with a digital device (LaMotte Company, model $\mathrm{n}^{\circ}$ 2020e), water temperature $\left({ }^{\circ} \mathrm{C}\right)$ and dissolved oxygen $(\mathrm{mg} / \mathrm{L})$ obtained using a digital oximeter (YSI incorporated-model YSI 550A), as well as total suspended material $(\mathrm{mg} / \mathrm{L})$, chlorophyll-a $(\mu \mathrm{g} / \mathrm{L})$, total nitrogen $(\mu \mathrm{g} / \mathrm{L})$, and total phosphate $(\mu \mathrm{g} / \mathrm{L})$, obtained following Teixeira et al. (1965), Goltermam et al. (1978), Zagatto et al. (1981) and Mackereth et al. (1978), respectively. We selected these variables because they are recognized as related to water quality and underwater visibility, primary production of the system and to the metabolism of fish. This long-term data set of limnological variables provide us significant fluctuations of the variables, making it fundamental to detect emerging relationships between the environment and the biota.

\section{Data analyses}

Occurrence and abundance data of C. kelberi were obtained for each sample across years. Abundance data were indexed according to the catch per unit effort (CPUE; number of individuals $/ 1000 \mathrm{~m}^{2}$ of gillnets in $24 \mathrm{~h}$ ). To investigate whether those variables related to the underwater visibility affect the invasion success of C. kelberi, we fitted regression models to occurrence and abundance data (response variables) separately, considering all limnological variables (explanatory variables). We choose to use regression models in order to find significant effects of the explanatory variables on C. kelberi occurrence and abundance. For this, we evaluated if the estimates of the beta parameters were significant (p-value), as well as their effect (positive or negative).

Before model construction, we evaluated 
Spearman correlations among explanatory variables, which did not suggest issues related to multicollinearity. In addition, samples with missing environmental data were excluded from analyses (136 samples $-16.42 \%$ in all data set), resulting in 692 samples for the occurrence model and 314 samples for the abundance model (see Table S1 in Supplementary Material 1 for details). Because occurrence data was binary and abundance data was continuous, we used Generalized Linear Mixed Models (GLMM) with binomial and normal errors, respectively; abundance data was log-transformed prior to model fitting. Mixed effects models allow for the use of random terms, which are important to consider where there is non-independence among samples (Zuur et al. 2009). As our sampling design involved different but the same sites of the floodplain that were sampled over several years, the year of sampling and the identity of sampling sites were used as random effects on the intercepts of models. This structure accounts for the particularities of each site and year but still focus on the main effects of all predictor variables (Zuur et al. 2009). We compared models with and without random effects using the Akaike's Information Criteria (AIC) to check if the inclusion of random terms improved model performance. In practice, in our models, we did not focus on the effect of time and sites because limnological variables may vary according to annual flood pulses at different sites and this could reflect in specific changes in the biota. In fact, this would be an effect of annual and spatial changes and not fluctuations of the limnological predictors themselves. Therefore, we considered these models as best options to find possible effects of limnological variables on the occurrence and abundance of C. kelberi. Besides, we were only interested in the overall effect of each visibility-related predictor, rather than on each site- or year-related particularity. Global models were fit using all predictors but the final models only included those variables whose coefficients were significant $(\mathrm{p}<0.05)$ and had low variance inflation factor (VIF < 2). All analyses were performed in the $\mathrm{R}$ environment ( $\mathrm{R}$ Development Core Team 2017) using functions glmer and lmer from the lme4 package (Bates et al. 2015).

\section{RESULTS}

The regression models identified significant limnological variables for both occurrence and abundance of C. kelberi in the upper Paraná River floodplain. The GLMM using the occurrence data of C. kelberi as response variable showed that turbidity and dissolved oxygen significantly influenced the presence of C. kelberi (Table 1), with turbidity decreasing the probability of occurrence of this species, whereas this species was likely present in waters with high oxygen levels (Figure 2).

On the other hand, the regression model using the abundance data of C. kelberi as response variable showed that dissolved oxygen and concentration of chlorophyll-a were those variables that significantly influenced the abundance of the species (Table 2). In this case, the abundance of C. kelberi decreased with dissolved oxygen and increased with chlorophyll-a (Figure 3). Then, greater amounts of dissolved oxygen in the environment coincided with few individuals of C. kelberi, whereas greater the concentration of chlorophyll-a had a positive relationship with the abundance of C. kelberi.

For both models, the inclusion of random effects significantly improved the quality of the model, considering the AIC, when compared with the model without random effects $\triangle A$ AIC for occurrence model $=145.3$; $\triangle$ AIC for abundance

Table 1. Generalized linear mixed model (GLMM) results for occurrence data of Cichla kelberi with the estimate of the significant parameters, standard error, $Z$ value and the probability of finding a $Z$ value lower than the one obtained $(p<0.05)$. Only the fixed part of the model is shown. *Significant values.

\begin{tabular}{ccccc}
\hline & Estimate & Std. Error & Z value & $\mathrm{p}$ \\
\hline Intercept & -1.033 & 0.463 & -2.231 & $0.026^{*}$ \\
Turbidity & -0.020 & 0.006 & -3.298 & $<0.05^{*}$ \\
Dissolved oxygen & 0.168 & 0.052 & 3.221 & $0.001^{*}$ \\
\hline
\end{tabular}



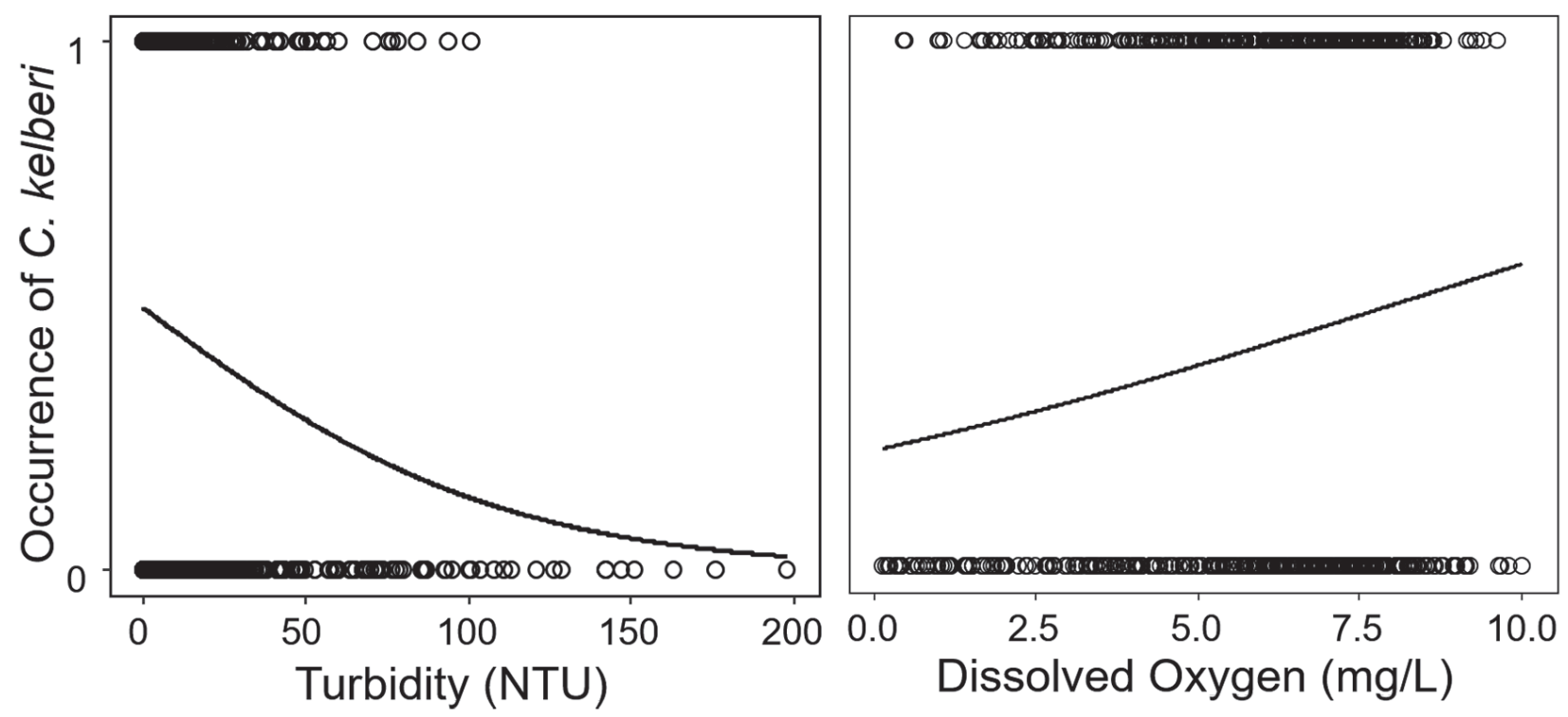

Figure 2. Relationship between the occurrence of Cichla kelberi and the two significant limnological variables: turbidity (left) and dissolved oxygen (right). The lines represent the effect of the limnological variable in the occurrence of $C$. kelberi.

Table 2. Linear mixed effects model (LMM) results for abundance data of Cichla kelberi with the estimate of parameters, standard error, $Z$ value and the probability of finding a $Z$ value lower than the one obtained $(\mathrm{p}<$ 0.05). Only the fixed part of the model is shown. *Significant values.

\begin{tabular}{ccccc}
\hline & Estimate & Std. Error & Z value & $\mathrm{p}$ \\
\hline Intercept & 2.454 & 0.199 & 12.303 & \\
Dissolved oxygen & -0.058 & 0.026 & -2.200 & $0.028^{*}$ \\
Chlorophyll-a & 0.009 & 0.004 & 2.249 & $0.023^{*}$ \\
\hline
\end{tabular}
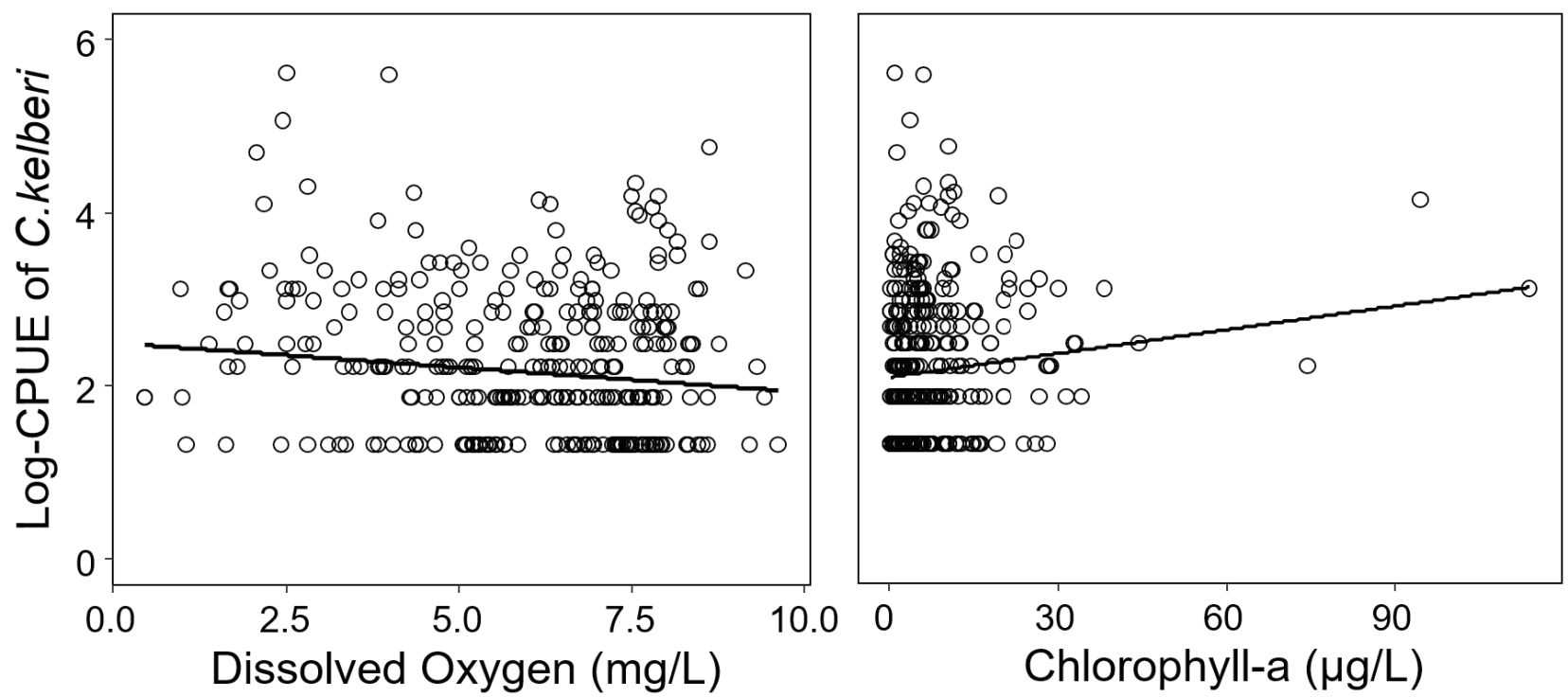

Figure 3. Relationship between the abundance of Cichla kelberi and two significant limnological variables: dissolved oxygen (left) and concentration of chlorophyll-a (right). The lines represent the effect of the limnological variable on the abundance (catch per unit effort; CPUE) of C. kelberi. 
model $=28.4)$. The abundance model did not present overdispersion or trends in residuals (Figure S1 in Supplementary Material 2).

\section{DISCUSSION}

Our findings showed that, in addition to turbidity, other limnological variables were determinants for the occurrence and abundance of C. kelberi, as dissolved oxygen and concentration of chlorophyll-a. Therefore, the variables related to underwater visibility are not the only important drivers for the successful invasion of C. kelberi in the upper Paraná River floodplain. The turbidity still is an important driver for the occurrence (i.e., presence/absence) of C. kelberi, but variables related to metabolism and productivity of fish species are more important to regulate its abundance. Therefore, since the invasion of $C$. kelberi in the upper Paraná River basin, it was believed that appropriate conditions (as higher transparency proposed by Espínola et al. 2010) allowed a higher invasibility of this species in new environments, but analyzing its abundance along several years revealed that its population growth is controlled by other limnological features.

These significant limnological variables to the variation of the occurrence and abundance of C. kelberi tend to vary in the floodplain along the hydrological cycles, besides varying among sites (Rodrigues et al. 2002). Temporally, the values of these variables tend to be similar among sites because periods of high water homogenize the entire plain (all environments show similar limnological features; Thomaz et al. 2007). However, as the water recedes, each site tends to present particular limnological features. On the other hand, the spatial variation is due to several dams that are located above the floodplain: the Paraná River is the most affected system, with distinct values of the limnological variables when compared to Ivinhema and Baía rivers. It is even affirmed that the Paraná River is suffering with impacts such as oligotrophication (Oliveira et al. 2018), influencing directly in variables related to underwater visibility and productivity of the system. Therefore, despite the temporal and spatial variabilities, the amount of different values in the long-term data set utilized allowed us a better investigation of our question, considering all the limnological conditions in the environments of the floodplain.

The environments of the Paraná River were the first ones where it was recorded the first occurrence of C. kelberi (unpublished data), river known by its lower values of turbidity due to sedimentation in several upstream reservoirs (Oliveira et al. 2018; see Table A1 in Appendix 1). Therefore, we believe that these lower values of turbidity were essential for the invasion and establishment by this species in the floodplain. Espínola et al. (2010) found, in their results, that water transparency (proxy of turbidity) was one of the most important variables to explain the occurrence of C. kelberi in reservoirs of the upper Paraná River basin. At Rosana reservoir, also in the upper Paraná River basin, the introduction of $C$. kelberi let to a decline in native fish diversity (Pelicice \& Agostinho 2009, Pelicice et al. 2015). Espínola et al. (2010) argue that, at the same reservoir, there were low values of water transparency, explaining the occurrence of $C$. kelberi, since this species is a daytime visual predator with high feeding plasticity (Novaes et al. 2004, Fugi et al. 2008).

Allied with turbidity, dissolved oxygen was also significant for the occurrence of C. kelberi. This variable is known to determine the distribution of fish species (Miranda 2000). For C. kelberi, its occurrence is more common in environments with higher concentrations of dissolved oxygen, since situations with low concentrations of oxygen depress metabolism of fish (Pörtner et al. 2004). However, dissolved oxygen also regulates the abundance of $C$. kelberi in the floodplain. This relationship showed lower abundance of the species in environments of the plain with higher values of dissolved oxygen. Calls attention that the highest abundance of the species occurred in low concentration of oxygen (around $2.5 \mathrm{mg} / \mathrm{L}$ ). We believe that these contrasts between the abundance and occurrence of C. kelberi may have favored its establishment in the floodplain, suggesting that this species is tolerant to lower concentrations of dissolved oxygen. Therefore, this may have conferred some advantages over most native fish species (Lagos et al. 2017).

Another significant variable for the abundance of C. kelberi was chlorophyll-a, a proxy for system productivity. The positive association between the abundance of C. kelberi and the concentration of chlorophyll-a revealed that the species increases 
its abundance in locations where productivity is higher. The hypothesis of dynamic equilibrium for invasive species predicts that productivity and disturbance are factors that, together, affect the invasion process in new environments (Huston 1979, 2004). The upper Paraná River floodplain, besides being considered one of the most pristine area within the basin, is not an environment free from anthropogenic disturbances. The construction of dams upstream the plain affects and disrupts the natural hydrological cycle, altering the minimum (due to continued water releases from the dam) and the maximum (reservoirs retain water) values of the hydrograph, leading to higher water levels during dry periods and to lower water levels (decrease in intensity) during floods. Besides the disturbance, the productivity of floodplain lakes may reach high values, presenting higher productivity in relation to the main river (see Table A2 in Appendix 1). Thereby, we may suggest that $C$. kelberi shows a preference for lentic environments, since these environments have propitious conditions that may facilitate its establishment, as well as reservoirs, as suggested by Espínola et al. (2010).

This significant positive influence of chlorophyll-a in the abundance of C. kelberi appears to be a result of a bottom-up process, in which the increase in phytoplanktonic productivity reflects in the increase in abundance of C. kelberi population. Some studies have already shown the relationship between the trophic state of the environment with the abundance of invasive species of fish (Vatland \& Budy 2007, Bajer et al. 2015, Lechelt \& Bajer 2016). In general, environments that are more productive seem to favor the recruitment of juveniles and support greater biomass and abundance of invasive species (Lechelt \& Bajer 2016). And in this case, piscivore species benefit itself from the high availability of forage fish species and juvenile forms of largesized species (Luz-Agostinho et al. 2008, Pereira et al. 2016), facilitating the long-term success of invasion (Tonella et al. 2018). However, values of chlorophyll-a have great variability throughout the years, due to flood and dry periods, increasing its concentration at low water levels and decreasing at high water levels (Rodrigues et al. 2002). This may explain why $C$. kelberi has kept its abundance in low values over time (Agostinho et al. 2004c).

Our results provide important insights on the main environmental drivers of the establishment process of C. kelberi in the upper Paraná River floodplain. It was possible to observe that the variables explaining the presence of the species, in the floodplain, are not necessarily those that regulate its population density. The presence of regions with high visibility and high concentration of oxygen were determinants of its occurrence. However, system productivity and regions with low oxygen concentrations were those that regulated the abundance of the species. Furthermore, it seems that the natural dynamics of this riverfloodplain system (i.e., hydrological cycles) and its high environmental heterogeneity (i.e., presence of lentic and lotic environments) were fundamental for keeping at lower values the abundance of this invasive species. This conclusion was possible due to the several variabilities found in the long data set, regarding the data of the species (occurrence and abundance) and the data of the limnological variables. Besides, the fact that the inclusion of random effects remarkably improved the quality of the models reveal that there are important idiosyncrasies that should be investigated further. Although the floodplain inevitably suffers from anthropogenic impacts, our findings suggest that the maintenance of some natural features of the system provides some resistance to prevent the outspread of invasive species.

\section{ACKNOWLEDGMENTS}

The authors would like to thank the Núcleo de Pesquisas em Limnologia, Ictiologia e Aquicultura (Nupélia) of the Universidade Estadual de Maringá (UEM) for providing the sampling and logistical support; the Project Pesquisas Ecológicas de Longa Duração (PELD) for delivering the data. The authors would also like to thank the Conselho Nacional de Desenvolvimento Científico e Tecnológico (CNPq) and Coordenação de Aperfeiçoamento de Pessoal de Nivel Superior (CAPES) for having granted the scholarship to A.C.R., C.M.M., C.P.N., G.F.A., J.C.A., M.H.S., M.J.M.G., M.P.C., M.G.B. and M.T.B.

\section{REFERENCES}

Agostinho, A. A., Julio Jr, H. F., \& Petrere Jr, M. 1994. Itaipu reservoir (Brazil): impacts of the impoundment on the fish fauna and fisheries. 
In: I. G. Cowx (Ed.), Rehabilitation of freshwater fisheries. pp. 171-184. United Kingdom: Fishing News Books.

Agostinho, A. A., Gomes, L. C., Thomaz, S. M., Hahn, N. S. 2004a. The upper Paraná River and its floodplain: main characteristics and perspectives for management and conservation. In: S. M. Thomaz, A. A. Agostinho \& N. S. Hahn (Eds.), The upper Paraná River and its floodplain: physical aspects, ecology and conservation. pp. 381--393. Leiden: Backhuys Publishers.

Agostinho, A. A., Thomaz, S. M., \& Gomes, L. C. 2004b. Threats for biodiversity in the floodplain of the upper Paraná River: effects of hydrological regulation by dams. Ecohydrology \& Hydrobiology, 4(3), 255-286.

Agostinho, A. A., Bini, L. M., Gomes, L. C., Julio Junior, H. F., Pavanelli, C. S., \& Agostinho, C. S. 2004c. Fish assemblages. In: S. M. Thomaz, A. A. Agostinho \& N. S. Hahn (Eds.), The upper Paraná River and its floodplain: physical aspects, ecology and conservation. pp. 223-246. Leiden: Backhuys Publishers.

Agostinho, A.A., Gomes, L. C., \& Pelicice, F. M. 2007a. Ecologia e Manejo de Recursos Pesqueiros em Reservatórios do Brasil. Maringá: EDUEM: p. 260.

Agostinho, A. A., Pelicice, F. M., Petry, A. C., Gomes, L. C., \& Júlio Jr., H. F. 2007b. Fish diversity in the upper Paraná River basin: habitats, fisheries, management and conservation. Aquatic Ecosystem Health \& Management, 10(2), 174186. DOI: $10.1080 / 14634980701341719$

Bajer, P. G., Cross, T. K., Lechelt, J. D., Chizinski, C. J., Weber, M. J., \& Sorensen, P. W. 2015. Acrossecoregion analysis suggests a hierarchy of ecological filters that regulate recruitment of a globally invasive fish. Diversity and Distributions, 21(5), 500-510. DOI: 10.1111/ ddi. 12315

Bates, D., Maechler, M., Bolker, B., \&Walker, S. 2015. Fitting linear mixed-effects models using lme4. Journal of Statistical Software, 67(1), 1-48. DOI: 10.18637/jss.v067.i01

Catford, J. A., Jansson, R., \& Nilsson, C. 2009. Reducing redundancy in invasion ecology by integrating hypotheses into a single theoretical framework. Diversity and Distributions, 15(1), 22-40. DOI: 10.1111/j.1472-4642.2008.00521.x

Clusa, L., Miralles, L., Fernández, S., García-
Vázquez, E., \&Dopico, E. 2018. Public knowledge of alien species: a case study on aquatic biodiversity in North Iberian rivers. Journal of Nature Conservation, 4, 53-61. DOI: 10.1016/j. jnc.2018.01.001

Cook, C. D. K., \& Lüönd, R. 1982. A revision of the genus Hydrilla (Hydrocharitaceae). Aquatic Botany, 13, 485-504. DOI: 10.1016/03043770(82) 90074-2

Espínola, L. A., \& Júlio Júnior, H. F. 2007. Espécies invasoras: conceitos, modelos e atributos. Interciência, 32(9), 580-585.

Espínola, L. A., Minte-Vera, C. V., \& Júlio-Jr, H. F. 2010. Invasibility of reservoir in Paraná Basin, Brazil, to Cichla kelberi Kullander and Ferreira, 2006. Biological Invasions, 12(6), 1873-1888. DOI: $10.1007 / \mathrm{s} 10530-009-9598-\mathrm{x}$

Essl, F., Dullinger, S., Rabitsch, W., Hulme, P. E., Hülbe, K., Jarošík, V., Kleinbauer, I., Krausmann, F., Kühn, I., Nentwig, W., Vilà, M., Genovesi, P., Gherardi, F., Desprez-Loustau, M., Roques, A., \& Pyšek, P. 2011. Socioeconomic legacy yields an invasion debt. Proceeding of the National Academy of Sciences of the United States of America, 108(1), 203-207. DOI: 10.1073/ pnas. 1011728108

Fugi, R., Luz-Agostinho, K. D. G., \& Agostinho, A. A. 2008. Trophic interaction between an introduced (peacock bass) and a native (dogfish) piscivorous fish in a Neotropical impounded river. Hydrobiologia, 607(1), 143-150. DOI: 10.1007/s 10750-008-9384-2

Gois, K. S., Pelicice, F. M., Gomes, L. C., \& Agostinho, A. A. 2015. Invasion of an Amazonian cichlid in the Upper Paraná River: facilitation by dams and decline of a phylogenetically related species. Hydrobiologia, 746(1), 401-413. DOI: 10.1007/ s10750-014-2061-8

Golterman, H. L., Clyno, R. S., \& Ohnstad, M. A. M. 1978. Methods for physical and chemical analysis of freshwaters. 2nd ed. Oxford: Blackwell: p. 315.

Graça, W. J., \& Pavanelli, C. S. 2007. Peixes da planície de inundação do alto rio Paraná e áreas adjacentes. Maringá: EDUEM: p. 241.

Granzotti, R. V., Miranda, L. E., Agostinho, A. A., \& Gomes, L. C. 2018. Downstream impacts of dams: shifts in benthic invertivorous fish assemblages. Aquatic Sciences, 80:28. DOI: 10.1007/s00027-018-0579

Huston, M. A. 1979. A general hypothesis of species 
diversity. The American Naturalist, 113(1), 81101. DOI: $10.1086 / 283366$

Huston, M. A. 2004. Management strategies for plant invasions: manipulating productivity, disturbance, and competition. Diversity and Distributions, 10(3), 167-178. DOI: 10.1111/j.1366-9516.2004.00083.x

Júlio Júnior, H. F., Dei Tós, C., Agostinho, A. A., \& Pavanelli, C. S. 2009. A massive invasion of fish species after eliminating a natural barrier in the upper rio Paraná basin. Neotropical Ichthyology, 7(4), 709-718. DOI: 10.1590/S167962252009000400021

Junk,W. J., Bayley, P. B., \& Sparks, R.E. 1989. The flood pulse concept in river-floodplain systems. In: P. D. Dodge (Ed.), Proceedings of the International Large River Sysmposium. Canadian Special Publication of Fisheries and Aquatic Sciences. pp. 110-127. Ontario, Canada.

Langeland, K. A. 1996. Hydrilla verticillata (L.f.) Royle (Hydrocharitaceae), "The perfect aquatic weed”. Castanea, 61, 293-304.

Lagos, M. E., Barneche, D. R., White, C. R., \& Marshall, D. J.2017. Do low oxygen environments facilitate marine invasions? Relative tolerance of native and invasive species to low oxygen conditions. Global Change Biology, 23(6), 23212330. DOI:10.1111/gcb.13668

Lechelt, J. D., \& Bajer, P. G. 2016. Elucidating the mechanism underlying the productivityrecruitment hypothesis in the invasive common carp. Aquatic Invasions, 11(4), 469-482. DOI: 10.3391/ai.2016.11.4.11

Leuven, R. S. E. W., Boggero, A., Bakker, E. S., Elgin, A. K., \& Verreycken, H. 2017. Invasive species in inland waters: from early detection to innovative management approaches. Aquatic Invasions, 12(3), 269-273. DOI: 10.3391/ai.2017.12.3.01

Luz-Agostinho, K. D. G., Agostinho, A. A., Gomes, L. C., \& Júlio Jr., H. F. 2008. Influence of flood pulses on diet composition and trophic relationships among piscivorous fish in the upper Paraná River floodplain. Hydrobiologia, 607, 187-198. DOI: $10.1007 / \mathrm{s} 10750-008-9390-4$

MacKereth, F. Y. H., Heron, J., \& Talling, J. J. 1978. Water analysis: some revised methods for Limnologists. Freshwater Biological Association, $36,1-120$.

Melbourne, B. A., Cornell, H. V., Davies, K. F., Dugae, C. J., Elmendorf, S., Freestone, A. L.,
Hall, R. J., Harrison, S., Hastings, A., Holland, M., Holyoak, M., Lambrinos, J., Moore, K., \& Yokomizo, H. 2007. Invasion in a heterogeneous world: resistance, coexistence or hostile takeover? Ecology Letters, 10(1), 77-94. DOI: 10.1111/j.1461-0248.2006.00987.x

Miranda, L. E., Driscoll, M. P., \& Allen, M. S. 2000. Transient physicochemical microhabitats facilitate fish survival in inhospitable aquatic plant stands. Freshwater Biology, 44(4), 617-628. DOI: 10.1046/j.1365-2427.2000.00606.x

Mouillot, D., Graham, N. A. J., Villéger, S., Mason, N. W. W., \& Bellwood, D. R. 2013. A functional approach reveals community responses to disturbances. Trends in Ecology \& Evolution, 28(3), 167-177. DOI: 10.1016/j.tree.2012.10.004

Novaes, J. L. C., Caramaschi, E. P., \& Winemiller, K. O. 2004. Feeding of Cichla monoculus Spix, 1829 (Teleostei: Cichlidae) during and after reservoir formation in the Tocations River, Central Brazil. Acta Limnologica Brasiliensia, 16(1), 41-49.

Oliveira, A. G., Baumgartner, M. T., Gomes, L. C., Dias, R. M., \& Agostinho, A. A. 2018. Long-term effects of flow regulation by dams simplify fish functional diversity. Freshwater Biology, 63(3), 293-305. DOI: 10.1111/fwb.13064

Ortega, J. C. G., Dias, R. M., Petry, A. C., Oliveira, E. F., \& Agostinho, A. A. 2015. Spatio-temporal organization patterns in the fish assemblages of a Neotropical floodplain. Hydrobiologia, 745, 31-41. DOI: 10.1007/s10750-014-2089-9

Ota, R. R., Deprá, G. C., Graça, W. J., \& Pavanelli, C. S. 2018. Peixes da planície de inundação do alto rio Paraná e áreas adjacentes: revised, annotated and updated. Neotropical Ichthyology, 16(2), e170094. DOI: 10.1590/1982-0224-20170094

Pelicice, F. M., \& Agostinho, A. A. 2009. Fish fauna destruction after the introduction of a nonnative predator (Cichla kelberi) in a Neotropical reservoir. Biological Invasions, 11(8), 1789-1801. DOI: 10.1007/s10530-008-9358-3

Pelicice, F. M., Vitule, J. R. S., Lima Júnior, D. P., Orsi, M. L., \& Agostinho, A. A. 2014. A serious new threat to Brazilian freshwater ecosystems: the naturalization of nonnative fish by decree. Conservation Letters, 7(1), 55-60. DOI: 10.1111/ conl.12029

Pelicice, F. M., Latini, J. D., \& Agostinho, A. A. 2015. Fish fauna disassembly after the introduction of a voracious predator: main drivers and the role 
of the invader's demography. Hydrobiologia, 746(1), 271-283. DOI: 10.1007/s10750-014-1911-8

Pereira, L. S., Agostinho, A. A., \& Delariva, R. L. 2016. Effects of river damming in Neotropical piscivorous and omnivorous fish: feeding, body condition and abundances. Neotropical Ichthyology, 14(1), el50044. DOI: 10.1590/19820224-20150044

Pörtner, H. O., Mark, F. C., \& Bock, C. 2004. Oxygen limited thermal tolerance in fish?: Answers obtained by nuclear magnetic resonance techniques. Respiratory Physiology \& Neurobiology, 141(3), 243-260. DOI: 10.1016/j. resp.2004.03.011

Queiroz-Sousa, J., Keith, S. A., David, G. S., Brandão, H., Nobile, A. B., Paes, J. V. K., Souto, A. C., Lima, F. P., Silva, R. J., Henry, R., \& Richardson, K. 2019. Species richness and functional structure of fish assemblages in three freshwater habitats: effects of environmental factors and management. Journal of Fish Biology. 95(4):1125-1136. DOI: 10.1111/jfb.14109

R Core Team. 2017. R: A language and environment for statistical computing. R Foundation for Statistical Computing, Vienna, AT. http:// www.R-project.org/

Rahel, F. J. 2000. Homogenization of fish faunas across the United States. Science, 288(5467), 854-856. DOI: 10.1126 /science.288.5467.854

Rodrigues, L. C., Train, S., Roberto, M. C., \& Pagioro, T. A. 2002. Seasonal fluctuation of some limnological variables on a floodplain lake (Patos lagoon) of the Upper Paraná River, Mato Grosso do Sul State, Brazil. Brazilian Archives of Biology and Technology, 45(4), 499-513. DOI: 10.1590/S1516-89132002000600014

dos Santos, N. C. L., García-Berthou, E., Dias, J. D., Lopes, T. M., Affonso, I. P., Severi, W, Gomes, L. C., \& Agostinho, A. A. 2018. Cumulative ecological effects of a Neotropical reservoir cascade across multiple assemblages. Hydrobiologia, 819(1), 77-91. DOI: $10.1007 / \mathrm{s} 10750-018-3630-\mathrm{z}$

Simberloff, D., Martin, J. L., Genovesi, P., Maris, V., Wardle, D. A., Aronson, J., Courchamp, F., Galil, B., García-Berthou, E., Pascal, M., Pyšek, P., Sousa, R., Tabacchi, E., \& Vilà, M. 2013. Impacts of biological invasions: what's what and the way forward. Trends in Ecology \& Evolution, 28(1), 58-66. DOI: 10.1016/j.tree.2012.07.013

Stevaux, J. C., Martins, D. P., \& Meurer, M. 2009.
Changes in a large regulated tropical river: the Paraná River downstream from the Porto Primavera Dam, Brazil. Geomorphology, 113(3-4), 230-238. DOI: $10.1016 / \mathrm{j}$. geomorph.2009.03.015

Strayer, D. L. 2010. Alien species in fresh waters: ecological effects, interactions with other stressors, and prospects for the future. Freshwater Biology, 55(s1), 152-174. DOI: 10.1111/j.1365-2427.2009.02380.x

Takeda, A. M., Fujita, D. S., De Melo, S. M., Ibarra, J. A., De Butakka, C. M. M., De Oliveira, D. P., Braga, C. P., Fujita, R. H., Rosin, G. C., \& Fernandes, S. E. P. 2003. Comunidade zoobentônica. In: UEM - NUPÉLIA/PELD. A planície de inundação do alto rio Paraná: Relatório Técnico-site 6 . Maringá. pp. 39-51.

Teixeira, C., Tundisi, J. G., \& Kutner, M. B. 1965. Plankton studies in magrove II: the standingstock and some ecological factors. Boletim do Instituto Oceanográfico, 14, 13--41. DOI: 10.1590/S0373-55241965000100002

Thomaz, S.M., Bini, L. M., \&Bozelli, R. L. 2007.Floods increase similarity among aquatic habitats in river-floodplain systems. Hydrobiologia, 579(1), 1-13. DOI: 10.1007/s10750-006-0285-y

Tonella, L. H., Fugi, R., Vitorino Jr., O. B., Suzuki, H. I., Gomes, L. C., \& Agostinho, A. A. 2018. Importance of feeding strategies on the longterm success of fish invasions. Hydrobiologia, 817(1), 239-252. DOI: $10.1007 / \mathrm{s} 10750-017-$ 3404-z

Vatland, S., \& Budy, P. 2007. Predicting the invasion success of an introduced omnivore in a large, heterogeneous reservoir. Canadian Journal of Fish and Aquatic Science, 64(10), 1329-1345. DOI: $10.1139 /$ f07-100

Villéger, S., Blanchet, S., Beauchard, O., Oberdorff, T., \& Brosse, S. 2011. Homogenization patterns of the world's freshwater fish faunas. Proceedings of the National Academy of Sciences, 108(44), 18003-18008. DOI: 10.1073/pnas.1107614108

Vitule, J. R. S., Freire, C. A., Vazquez, D. P., Nuñes, M. A., \& Simberloff, D. 2012. Revisiting the potential conservation value of nonnative species. Conservation Biology, 26(6), 1153-1155. DOI: 10.1111/j.1523-1739.2012.01950.x

Zagatto, E. A. G., Jacintho, A. O., Reis, B. F, Krug, F. J., Bergammin-Filho, H., Pessenda, L. C. R., Mortatti, J., \& Giné, M. F. 1981. Manual de 
análise de plantas e águas empregando sistemas de injeção em fluxo. Piracicaba: CENA: p. 45

Zuur, A. F., Ieno, E. N., Walker, N. J., Saveliev, A.A., \& Smith, G. M. 2009. Meet the Exponential Family. In: A. F. Zuur, E. N. Ieno, N. J. Walker, A. A. Saveliev, \& G. M. Smith (Eds.), Mixed effects models and extensions in Ecology with R. pp. 193-208. New York: Springer.

\section{Supplementary Material:}

Figure S1. Distribution of residuals in relation to fitted values of the abundance model. The model did not present overdispersed residuals.

Table S1. Number of samples and marginal totals for each model of occurrence (Oc) and abundance (Ab; in parentheses) of Cichla kelberi from 21 sites in the upper Paraná River floodplain, sampled from 2000 to 2018.

Submitted: 1 September 2019

Accepted: 7 April 2020

Published on line: 15 June 2020

Associate Editors: Camila Barros and Nuria Pistón 


\section{Appendix 1}

Table A1. Descriptive statistics of significant environmental variables in the three rivers of the upper Paraná River floodplain. SD: standard deviation.

\begin{tabular}{lcccc}
\hline & $\mathrm{N}$ & Minimum & Mean (SD) & Maximum \\
\cline { 2 - 5 } & \multicolumn{4}{c}{ Turbidity (NTU) } \\
\hline Baía & 249 & 0.45 & $17.43(19.77)$ & 113.30 \\
Ivinhema & 244 & 0.36 & $30.03(34.89)$ & 198.00 \\
Paraná & 199 & 0.00 & $6.31(8.50)$ & 68.70 \\
\hline & \multicolumn{5}{c}{ Dissolved Oxygen (mg/L) } \\
\hline Baía & 249 & 0.11 & $5.32(2.11)$ & 9.42 \\
Ivinhema & 244 & 0.18 & $5.95(2.20)$ & 10.02 \\
Paraná & 199 & 0.34 & $6.17(1.99)$ & 9.68 \\
\hline & \multicolumn{5}{c}{ Chlorophyll-a (ug/L) } \\
\hline Baía & 249 & 0.00 & $9.80(13.98)$ & 124.50 \\
Ivinhema & 244 & 0.00 & $7.56(9.89)$ & 53.92 \\
Paraná & 199 & 0.20 & $6.23(11.89)$ & 113.76 \\
\hline
\end{tabular}

Table A2. Descriptive statistics of significant environmental variables in the four environments of the upper Paraná River floodplain. SD: standard deviation.

\begin{tabular}{|c|c|c|c|c|}
\hline & $\mathrm{N}$ & Minimum & Mean (SD) & Maximum \\
\hline & \multicolumn{4}{|c|}{ Turbidity (NTU) } \\
\hline Channels & 45 & 0.36 & $9.25(6.90)$ & 31.90 \\
\hline Connected floodplain lakes & 315 & 0.00 & $13.84(17.12)$ & 126.10 \\
\hline Isolated floodplain lakes & 154 & 0.45 & $41.41(40.82)$ & 198.00 \\
\hline \multirow[t]{2}{*}{ Rivers } & 178 & 0.00 & $9.94(9.41)$ & 47.10 \\
\hline & \multicolumn{4}{|c|}{ Dissolved Oxygen (mg/L) } \\
\hline Channels & 45 & 1.68 & $6.17(1.77)$ & 8.76 \\
\hline Connected floodplain lakes & 315 & 0.11 & $5.16(2.35)$ & 10.02 \\
\hline Isolated floodplain lakes & 154 & 0.66 & $5.76(1.93)$ & 9.64 \\
\hline \multirow[t]{2}{*}{ Rivers } & 178 & 1.64 & $6.82(1.53)$ & 9.68 \\
\hline & \multicolumn{4}{|c|}{ Chlorophyll-a (ug/L) } \\
\hline Channels & 45 & 0.20 & $4.20(4.07)$ & 18.66 \\
\hline Connected floodplain lakes & 315 & 0.00 & $8.93(11.37)$ & 113.76 \\
\hline Isolated floodplain lakes & 154 & 0.68 & $13.05(17.67)$ & 124.50 \\
\hline Rivers & 178 & 0.00 & $2.89(4.22)$ & 34.13 \\
\hline
\end{tabular}

